\section{Public access defibrillation}

\section{To the editor:}

In the October 2001 issue of CJEM the Canadian Association of Emergency Physicians Public Access Defibrillation (PAD) Working Group published their position statement in support of PAD programs. ${ }^{1}$ This follows a similar endorsement by the Canadian Heart and Stroke Foundation. ${ }^{2}$ While I applaud the efforts of our association in being proactive with regard to health technology assessment, I feel that a great impediment to PAD programs may come from the fact that most cardiac arrests do not occur in public places.

Survival to cardiac arrest is currently less than 5\% in Ontario. ${ }^{3,4}$ Obviously, something needs to be done. While early defibrillation by first responders (firefighters, police, emergency medical services [EMS]) has been shown to improve survival to cardiac arrest, ${ }^{3}$ the potential impact of a widespread layperson PAD program in the community may not. In a study of 1373 cardiac arrest cases over a 5-year period in the Ottawa region, approximately $85 \%$ of cardiac arrests occurred in private homes, $10 \%$ on the street and only $5 \%$ in large public places. ${ }^{4} \mathrm{~A}$ similar study is under way in 21 Ontario communities. In addition, $2 / 3$ of cardiac arrest victims were found to be in asystole; ${ }^{4}$ those cases could not be helped by defibrillation. Therefore, we can estimate that less than $3 \%$ of all cardiac arrest cases could benefit from such a PAD program. This being said, a person is 3 times more likely to survive if cardiopulmonary resuscitation (CPR) is performed immediately after collapse. ${ }^{5}$ Yet only 3\% of the Canadian population knows how to perform CPR. Al-

For reasons of space, letters may be edited for brevity and clarity. most 9 times out of 10, nothing is being done before EMS arrive. ${ }^{5}$ If only $50 \%$ of cardiac arrest cases were to receive immediate CPR, survival to cardiac arrest could be improved from the current $5 \%$ to over $30 \%{ }^{6}$

With those statistics in mind, and with an international trial under way evaluating the outcome of PAD programs in North America (The PAD Trial), it may be premature to endorse any PAD program at this moment. It may be that if more resources were devoted to increasing the bystander rate of CPR in the population, even better results could be achieved. Such a program would benefit the whole population, not just the few and far between cases of cardiac arrest that occur in public places.

Let's be cautious before we endorse PAD programs.

\section{Christian Vaillancourt, MD}

Research Fellow

University of Ottawa

Attending physician

Ottawa Hospital - Civic Campus

Ottawa, Ont.

\section{References}

1. Canadian Association of Emergency Physicians Public Access Defibrillation Working Group. Public access defibrillation programs [position statement]. CJEM 2001;3(4):267-8.

2. The Heart and Stroke Foundation of Canada. Communiqué submitted to The Standing Committee on Justice and Social Policy, Ottawa, Aug 30, 2001. Available: www.ontla.on.ca/hansard /committee_debates/37/parl/Session2/ju stice/J009.htm\#P595_138991 (accessed 2001 Dec 14).

3. Stiell IG, Wells GA, Field BJ, Spaite DW, De Maio VJ, Ward R, et al. Improved out-of-hospital cardiac arrest survival through the inexpensive optimization of an existing defibrillation program: OPALS study phase II. Ontario Prehospital Advanced Life Support. JAMA 1999;281:1175-81.

4. De Maio V, Stiell I, Wells G, Martin MT, Doherty J, Spaite DW, et al. Potential impact of public access defibrillation based upon cardiac arrest loca- tions [abstract]. Acad Emerg Med 2001;8:415-6.

5. Stiell IG, Wells GA, DeMaio VJ, et al. Modifiable factors associated with improved cardiac arrest survival in a multicenter basic life support/defibrillation system: OPALS Study Phase I results. Ontario Prehospital Advanced Life Support. Ann Emerg Med 1999;33:44-50.

6. De Maio VJ, Stiell IG, Wells GA, Martin MT, Spaite DW, Nichols G, et al, for the OPALS Study Group. The relationship between out-of-hospital cardiac arrest survival and community bystander cardiopulmonary resuscitation rates [abstract]. CJEM 2001;3(2):128.

\section{Propofol in the ED: Check your doses!}

\section{To the editor:}

Doses of $16-33 \mathrm{mg} / \mathrm{min}$ for patient-controlled sedation were repeatedly quoted in Dr. Ducharme's commentary. ${ }^{1}$ These doses would be expected to result in general anesthesia within 10 minutes! Propofol infusions in the range of $20-40 \mathrm{mcg} / \mathrm{kg} / \mathrm{min}$ (i.e., $1.5-3 \mathrm{mg} / \mathrm{min}$ for a 70-kg patient) titrated to patient response with boluses of approximately $200 \mathrm{mcg} / \mathrm{kg}(15 \mathrm{mg})$ are more commonly used for procedural sedation. (Product monograph recommendations for surgical diagnostic sedation are for $25-75 \mathrm{mcg} / \mathrm{kg} / \mathrm{min}$ after $0.5-1.0 \mathrm{mg} / \mathrm{kg}$ bolus over 3 to 5 minutes.)

I have difficulty understanding how Dr. Ducharme could author a commentary on propofol that repeatedly quotes infusion rates for sedation that are over 10 times those recommended and used clinically. Although Dr. Ducharme undoubtedly has experience with intermittent mini-dose titration of propofol, his commentary suggests this is not the case with administering propofol infusions. Readers who utilize Dr. Ducharme's recommended propofol infusion rates of $16-33 \mathrm{mg} / \mathrm{min}$ for sedation will quickly find themselves managing an apneic, unconscious patient. Dr. Ducharme's proposed study on pa- 